\title{
Pengaruh Long Hot Water Treatment terhadap Perkecambahan dan Produksi Benih Tebu Bagal Mata Satu dan Dua
}

\section{Effect of Long Hot Water Treatment on Sugarcane Seed Germination and Production Of Single and Double Budded Cane Cutting}

\author{
Wiwit Wicaksono Jati ${ }^{1)}$, Ari Kristini ${ }^{1)}$, \& Lilik Koesmihartono Putra ${ }^{1)}$, \\ ${ }^{1)}$ Pusat Penelitian Perkebunan Gula Indonesia, Pasuruan, Indonesia \\ (Alamat korespondensi, E-mail: jatiwiwit@yahoo.co.id)
}

\begin{abstract}
ABSTRAK
Salah satu penyakit penting terbawa benih adalah penyakit pembuluh yang disebabkan bakteri Leifsonia xyli sub sp xyli. Perlakuan Long Hot Water Treatment (LHWT) dapat mengendalikan penyakit tersebut tetapi menyebabkan penurunan perkecambahan. Tujuan penelitian ini ialah untuk mengetahui pengaruh LHWT terhadap perkecambahan beberapa varietastebu bina dan produksi benih tebu varietas bina. Penelitian dilakukan pada tahun 2015, di P3GI Pasuruan Jawa Timur. Penelitian menggunakan rancangan petak terbagi. Petak utama terdiri dari 5 varietas yaitu PSDK 923, Bululawang, VMC 76-16, PSJK 922, PS 862. Anak petak terdiri dari 6 perlakuan yaitu kontrol benih bagal mata satu dan bagal mata dua, LHWT dengan perendaman larutan fungisida dan urea pada benih bagal mata satu dan bagal mata dua, perawatans air panas suhu $50^{\circ} \mathrm{C} 10$ menit diikuti LHWT dan perendaman pada larutan fungisida dan urea pada benih bagal mata satu dan bagal mata dua. Hasil penelitian menunjukkan bahwa perlakuan pre-treatment pada suhu $50^{\circ} \mathrm{C} 10$ menit yang diikuti LHWT dengan perendaman dalam larutan fungisida dan urea 20 menit pada benih tebu bagal mata satu dan dua dapat mengurangi penurunan perkecambahan dan pertumbuhan benih pada semua varietas tebu. LHWT yang diikuti pre-treatment dapat meningkatkan produktivitas benih tebu dibandingkan LHWT tanpa pre-treatment.
\end{abstract}

Kata Kunci: fungisida, Leifsonia xyli sub sp xyli, perkecambahan, perendaman, urea.

\section{ABSTRACT}

One of sugarcane important disease is ratoon stunting disease caused by Leiifsonia xyli sub sp. xyli. This disease can be controlled by Long Hot Water Treatment (LHWT) on cane cuttings but it may cause a decrease in seed cane germination. This study was conducted to determine the effect of LHWT on germination from some sugarcane commercial varieties. This study was conducted in 2015 at P3GI Pasuruan, East Java. This experiment was carried out using a split plot design. The main plot consisted of five cultivated varieties namely PSDK 923, Bululawang, VMC 76-16, PSJK 922, and PS 862. The subplots consisted of six treatments including single budded cane cuttings without LHWT (control 1), two budded cane cuttings without LHWT (control2), single budded cane cuttings treated with LHWT followed by soaking in fungicide and urea solutions, two budded cane cuttings with LHWT followed 
by soaking in fungicide and urea solutions, single budded cane cuttings treated with pretreatment in hot water $50^{\circ} \mathrm{C}$ for 10 minutes followed by LHWT and soaking in fungicide and urea solutions, and two budded cane cuttings treated with pre-treatment in hot water $50^{\circ} \mathrm{C}$ for 10 minutes followed by LHWT and soaking in fungicide and urea solutions. The results showed that pre-treatment in hot water $50^{\circ} \mathrm{C}$ for 10 minutes followed by LHWT and soaking in fungicide and urea solutions at single and two buddedcane cuttings suppressed the impact of LHWT in decreasing seed cane germination for all varieties. Pre-treatment LHWT increased the productivity of sugarcane seeds compared to LHWT without pre-treatment.

Key words: fungicide, germination, Leifsonia xyli sub sp xyli, soaking, urea

\section{PENDAHULUAN}

Penggunaan bahan tanam atau benih yang bermutu merupakan modal dasar untuk mendapatkan produktivitas tebu yang tinggi. Selain mempunyai keunggulan tertentu, benih tebu bermutu harus memenuhi persyaratan murni, daya kecambah tinggi serta sehat, khususnya sehat dari penyakitsistemik seperti penyakit pembuluh (Ratoon Stunting Disease/ RSD). Salah satu upaya untuk memperoleh benih tebu sehat adalah dengan perlakuan air panas (Hot Water Treatment) pada benih (Putra, 1997). Tanaman tebu dapat sembuh dari penyakit RSD dengan perlakuan pemanasan (perlakuan air panas pada suhu $50^{\circ} \mathrm{C}$ selama2-3 jam) (Tiwari, 2012).

Tujuan perlakuan air panas pada benih tebu adalah untuk mematikan hama dan patogen yang terbawa melalui stek batang tebu (bagal). Perlakuan air panas padabenih tebu dibedakan menjadi 2 yaitu perlakuan air panas waktu pendek (Short Hot Water Treatment atau SHWT) dan perlakuan air panas waktu panjang (Long Hot Water Treatment atau LHWT). SHWT pada suhu $52^{\circ} \mathrm{C}$ selama 30 menit tidak efektif untuk mengendalikan RSD (Carvalho, 2016). LHWT awalnya ditujukan untuk pengendalian RSD, namun perlakuan ini juga dapat mengendalikan luka api, blendok dan CSD (Putra, 1997; Kristini,2000; Putra, 2005; Croft, 2011).

RSD merupakan penyakit penting pada tebu di Indonesia yang disebabkan oleh bakteri Leifsonia xyli subsp. xyli. Penyakit tersebut bersifat sistemik sehingga dapat ditularkan melalui benih tebu. Penggunaan benih yang terinfeksi patogen dapat memicu terjadinya degenerasi klonal suatu varietas (Sugiyarta, 1993). Kombinasi infeksi virus penyebab mosaik dan bakteri penyebab penyakit RSD dapat menyebabkan degenerasi varietas (Viswanathan, 2016).

Di Indonesia perlakuan HWT merupakan cara pengendalian RSD yang efektif karena varietas yang tahan RSD belum tersedia. Kerugian hasil yang diakibatkan oleh RSD dapat mencapai 1050\% (King, 1978; Handojo, 1982; Bailey \& Fox, 1984; Grisham, 1991), maka LHWT pada benih tebu akan menjadi sangat penting untuk pengendalian RSD. Kejadian RSD di Mumias, Kenya cukup tinggi yaitu mencapai $50 \%$ area sehingga tindakan pengendalian melalui perlakuan air panas dalam upaya mendapatkan benih sehat terus ditingkatkan (Mutonyi, 2016).

Perlakuan LHWT suhu $50^{\circ} \mathrm{C}$ selama 2 jam, dapat menurunkan daya kecambah 1030\% (Kristini, 2000). Perendaman bagal tebu yang telah diberi perlakuan air panas 
dalam larutan fungsida dan urea dapat meningkatkan perkecambahan benih tebu (Hardy, 1973; Goodall, 1998).

LHWT berdampak pada penurunan perkecambahan benih yang dapat mempengaruhi produktivitas tebu. Varietas tebu dan bentuk benih (bagal mata 1, 2 atau 3) diduga memberikan respon yang berbedabeda terhadap LHWT. Berdasarkan hal tersebut perlu dilakukan penelitian pengaruh LHWT pada benih tebu bagal mata 1 dan 2 dari beberapa varietas bina, serta upaya untuk meminimalisir dampak LHWT terhadap perkecambahan benih.

\section{METODE}

\section{Waktu dan tempat}

Penelitian ini dilakukan di Rumah Kaca Proteksi Tanaman dan Kebun Kejobo P3GI Pasuruan, Jawa Timur. Waktu penelitian selama 9 bulan, yang dimulai pada bulan Maret 2015 sampai dengan Nopember 2015.

\section{Bahan dan alat}

Bahan yang dibutuhkan dalam penelitian ini berupa benih tebu 5 varietas bina yaitu PSDK 923, Bululawang, VMC 76- 16, PSJK 922, PS 862. Benih yang digunakan adalah benih dengan daya kecambah $\geq 80 \%$. Bahan lain diantaranya media tanah, tray/kotak pembibitan, fungisida berbahan aktif Benomil dengan dosis 0,6 gr/liter, urea dengan dosis 3,6 gram/liter, pupuk Za 8 ku/ha dan SP 362 $\mathrm{ku} / \mathrm{ha}$.

Peralatan yang digunakan dalam penelitian antara lain: Water tank atau water bath, termometer, waring atau paranet, label, tali, ajir, spidol permanen, drum atau 9 ember besar, tabung gas elpiji dan alat untuk pengamatan pertumbuhan (meteran, hand counter, jangka sorong dan timbangan).

\section{Prosedur Penelitian}

Percobaan terdiri atas 2 kegiatan yaitu percobaan pengaruh LHWT pada perkecambahan benih di rumah kaca dan pengaruh LHWT pada produksi benih tebu di kebun. Percobaan menggunakan Rancangan Petak Terbagi atau Split Plot Design dengan petak utama adalah Varietas dan Anak Petak adalah Perlakuan (P1 = Kontrol bagal mata 1; P2 = Kontrol bagal mata $2 ; \mathrm{P} 3=$ LHWT dan post-treatment dengan fungisida dan urea pada bagal mata 1; P4 LHWT dan post-treatment dengan fungisida dan urea pada bagal mata 2, P5 = Pre-treatment LHWT dan post-treatment dengan fungisida dan urea pada bagal mata 1, P6 = Pre-treatment LHWT dan posttreatment dengan fungisida dan urea pada bagal mata 2). Pre-treatment merupakan perlakuan perendaman bagal ke dalam air panas pada suhu $50^{\circ} \mathrm{C}$ selama 10 menit sebelum LHWT. Percobaan di ulang 3 kali.

\section{Penyiapan Lahan dan Benih}

Pengolahan lahan dilakukan secara manual dengan mengacu baku teknis di kebun Percobaan Pasuruan. Benih tebu dari 5 varietas (PSDK 923, Bululawang, VMC 76-16, PSJK 922, PS 862) yang diuji berumur 8 bulan diambil dari Kebun Percobaan P3GI. Sebelum digunakan benih diuji viabilitasnya dan hanya benih dari kebun benih yang mempunyai daya kecambah $\geq 80 \%$ yang dipakai.

\section{Aplikasi LHWT}

Perlakuan LHWT pada benih dalam waring sebagai berikut: (1) Bagal mata satu tanpa perlakuan sebagai kontrol (P1); 
(2) bagal mata dua tanpa perlakuan sebagai kontrol (P2); (3) bagal mata satu dilakukan LHWT diikuti dengan posttreatment perendaman benih ke dalam larutan fungisida dan urea (P3); (4) pada bagal mata dua di lakukan LHWT diikuti dengan post-treatmentperendaman benih ke dalam larutan fungisida dan urea (P4); (5) bagal mata satu diberi pre-treatment (perendaman benih dalam air panas suhu $50^{\circ} \mathrm{C}$ selama 10 menit satu hari sebelum LHWT) kemudian LHWT dan diikuti posttreatment perendaman benih ke dalam larutan fungisida dan urea (P5); (6) bagal mata dua diberi pre-treatment (perendaman benih dalam air panas suhu $50^{\circ} \mathrm{C}$ selama 10 menit satu hari sebelum LHWT) kemudian LHWT dan diikuti post-treatment perendaman benih ke dalam larutan fungisida dan urea (P6) (Gambar 1). Setiap perlakuan terdiri dari 3 plot, setiap plot terdiri dari 3 juring. Dalam satu juring terdiri dari 48 matatunas. Satu waring benih untuk 1 plot yang terdiri dari 144 mata. pada benih berupa bagal dua mata, satu waring terdiri dari 72 bagal.

\section{Parameter percobaan}

\section{Perkecambahan Benih Tebu}

Perkecambahan tebu diamatipada saat umur 1 bulan dengan menghitung persentase perkecambahan tebu pada masing masing perlakuan. Perkecambahan benih dilakukan di rumah kaca pada tray plastik. Perhitungan persen perkecambahan adalah jumlah benih berkecambah dibagi jumlah seluruh benih yang digunakan pada setiap plot. Benih tersebut di pindah tanamkan setelah umur 1,5 bulan.

\section{Perubahan Fisik Mata Tunas}

Pada percobaan ini diamati perubahan fisik mata tunas. Pada parameter pengamatan ini diambil sampel sebanyak 20 mata tunas dalam satu waring yang diulang 3 kali. Persentase perubahan fisik mata tunas merupakan persen dari jumlah mata tunas yang berubah warna menjadi kecoklatan terhadap jumlah sampel mata tunas dalam satu waring.

\section{Taksasi Produksi dan Penangkaran}

Taksasi produksi merupakan metode untuk memperkirakan produksi tebu dengan perhitungan menggunakan data agronomis seperti jumlah batang, jumlah rumpun, berat batang, hama dan penyakit sebagai faktor koreksi yangdinyatakan dalam satuan luas. Taksasi penangkaran merupakan suatu metode perhitungan untuk memperkirakan kelipatan penggunaan dari suatu bahan tanam dalam satuan luas. Faktor juring/jumlah juring yang digunakan adalah 1.253 dengan panjang juring 6 meter, PKP 1 meter, gantangan 1 meter dan lebar got 0,5 meter. Pada perhitungan keperluan benih menggunakan 8 mata/ meter. Rumus perhitungan berat batang, jumlah juring per hektar, persen serangan mosaik, penggerek pucuk dan batang, taksasi produksi dan penangkaran tercantum pada Lampiran.

\section{Analisis Data}

Data yang diperoleh dianalisis menggunakan program Statistik versi 8.0 dengan tingkat kepercayaan $95 \%$. Apabila perlakuan dinyatakan berpengaruh, maka uji lanjut dilakukan menggunakan uji Beda Nyata Terkecil (BNT) 5\%. 


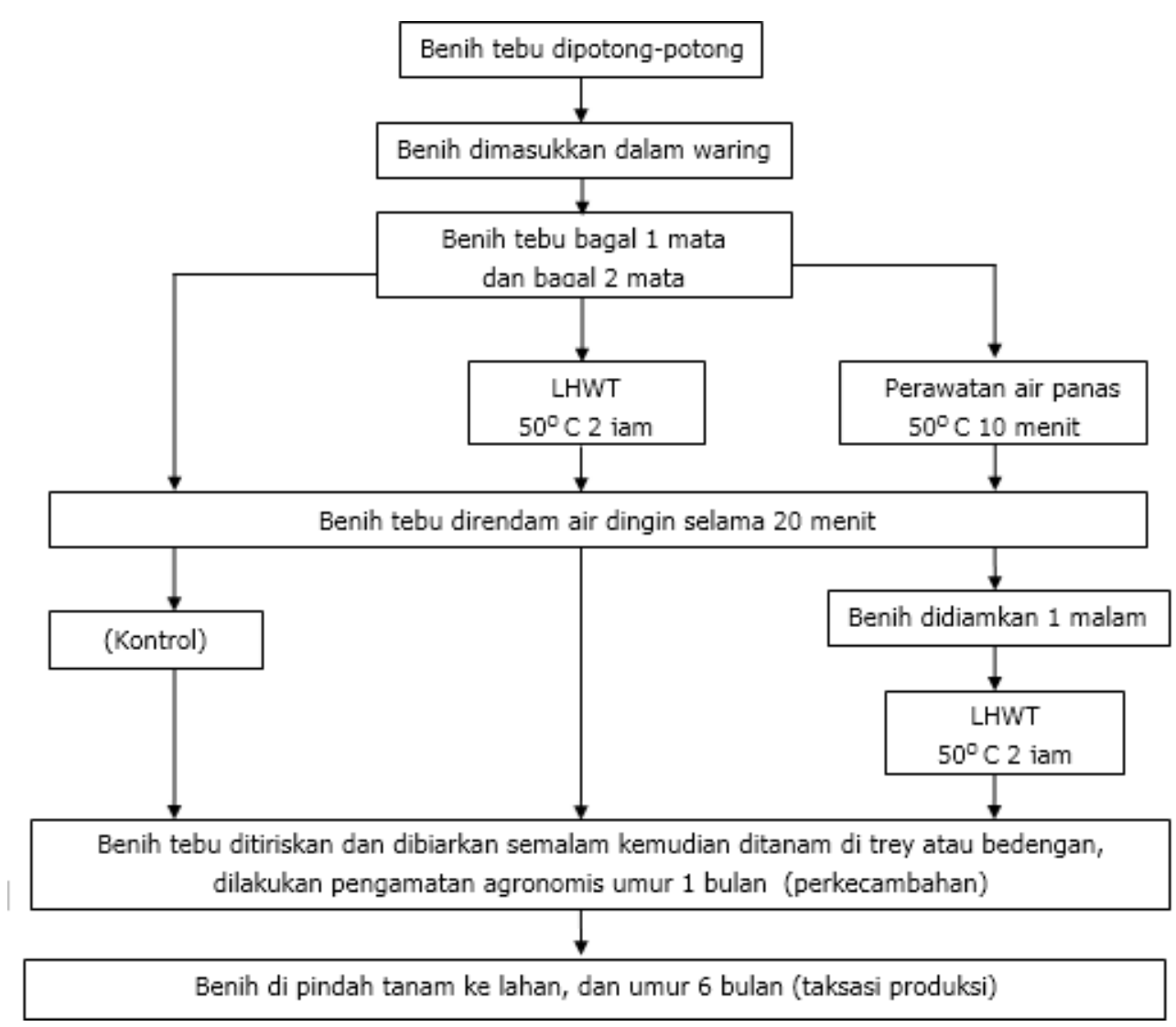

Gambar 1. Diagram alur metode penelitian perlakuan air panas waktu panjang, pretreatment dan post-treatment.

Figure 1. Research method flowchart of long hot water tratment, pre-tratment and posttreatment.

\section{HASIL DAN PEMBAHASAN}

\section{Pengaruh LHWT terhadap Perkecam- bahan Benih}

Pada parameter perkecambahan digunakan benih dengan viabilitas diatas $80 \%$. Hasil uji statistik menunjukkan bahwa tidak ada interaksi varietas dan perlakuan LHWT terhadap perkecambahan baik percobaan lapangan maupun rumah kaca. Hasil pengamatan perkecambahan setelah perlakuan LHWT pada beberapa varietas bina menunjukkan bahwa varietas PSDK 923, Bululawang, VMC 76-16, dan PS 862 memiliki persentase perkecambahan yang lebih rendah dibandingkan varietas PSJK

\section{2 (Tabel 1.).}

Hasil percobaan perkecambahan dirumah kaca menunjukkan bahwa P3 dan P 4 berbeda nyata dengan kontrol ataupun P5 dan P6 (Tabel 2.). Hal tersebut menunjukkan bahwa pada P3 masih mengalami penurunan perkecambahan akibat LHWT sebesar $30 \%$ dibandingkan dengan kontrol pada P1. Pada P4 masih mengalami penurunan perkecam-bahan akibat LHWT sebesar 11\%, dibandingkan dengan kontrol pada P2. Perendaman pada larutan fungisida dan urea pada bagal mata dua dapat menekan penurunan perkecambahan sebesar 9\%, namun pada bagal mata satu tidak berpengaruh. 
Perkecambahan pada P1 dan P2 merupakan perkecambahan yang normal karena $>55 \%$. Menurut (Singh, 2008) bahwa perkecambahan tebu normal di lahan tebu akan menurun sampai dengan $25 \%$ atau nilai perkecambahannya $55 \%$.

Tabel 1. Pengaruh mandiri varietas tebu terhadap persentase perkecambahan di rumah kaca.

Table 1. Independent effect of sugarcane varieties on germination percentage in greenhouse

\begin{tabular}{lc}
\hline \multicolumn{1}{c}{$\begin{array}{c}\text { Varietas } \\
\text { Varieties }\end{array}$} & $\begin{array}{c}\text { Perkecambahan }(\%) \\
\text { Germination }(\%)\end{array}$ \\
\hline PSDK 923 & $70,56 \mathrm{~b}$ \\
Bululawang & $65,28 \mathrm{~b}$ \\
VMC 76-16 & $61,39 \mathrm{~b}$ \\
PSJK 922 & $81,94 \mathrm{a}$ \\
PS 862 & $62,22 \mathrm{~b}$ \\
\hline
\end{tabular}

Angka-angka yang diikuti huruf yang sama menunjukkan tidak berbeda nyata berdasarkan uji BNT $5 \%$.

The numbers followed by the same letter showed no significant different based on the 5\% LSD test.

Tanaman tebu berkecambah apabila terjadi pemecahan gula sukrosa menjadi gula sederhana (glukosa dan fruktosa) dan dipengaruhi aktivitas hormon pada masingmasing varietas sehingga perkecambahan masing-masing varietas berbeda (Pawirosemadi, 2011). Selain faktor internal perkecambahan juga dipengaruhi oleh faktor eksternal. Hasil uji statistik menunjukkan bahwa tidak ada interaksi varietas dan perlakuan LHWT terhadap perkecambahan.

Pada Tabel 1 menunjukkan bahwa varietas PSJK 922 merupakan varietas yang tahan terhadap perlakuan LHWT dibandingkan 4 varietas lainnya. Varietas
VMC 76-16 merupakan varietas yang peka dibandingkan varietas lainnya, karena memiliki nilai persentase perkecambahan yang paling rendah. Perlakuan HWT selama 120 menit dapat menyebabkan kandungan protein, glukosa dan prolin rendah. Penurunan kandungan protein dan glukosa menyebabkan penurunan perkecambahan. Asam amino atau protein diperlukan pada saat perkecambahan (Haryuni, 2015).

Tabel 2. Pengaruh mandiri perlakuan LHWT terhadap perkecambahan di rumah kaca.

Table 2. Independent effect of LHWT treatments on germination in greenhouse

\begin{tabular}{cc}
\hline Varietas & $\begin{array}{c}\text { Perkecambahan } \\
(\%) \\
\text { Varieties }\end{array}$ \\
$\begin{array}{c}\text { Germination } \\
(\%)\end{array}$ \\
\hline P1 (K bagal mata 1) & $75.00 \mathrm{~b}$ \\
P2 (K bagal mata 2) & $68.67 \mathrm{~b}$ \\
P3 (LHWT + Post (F + & $47.00 \mathrm{~d}$ \\
U) ) mata 1 & \\
P4 (LHWT + Post (F + U & $57.00 \mathrm{c}$ \\
)) mata 2 & \\
P5 (Pre + LHWT + Post & $84.67 \mathrm{a}$ \\
(F + U)) mata 1 & \\
P6 (Pre + LHWT + Post & $77.33 \mathrm{ab}$ \\
(F + U)) mata 2 & \\
\end{tabular}

Angka-angka yang diikuti huruf yang sama menunjukkan tidak berbeda nyata berdasarkan uji BNT $5 \%$.

The numbers followed by the same letter showed no significant different based on the $5 \%$ LSD test.

Hasil Percobaan pada Tabel 2 menunjukkan bahwa perendaman pada larutan fungisida dan urea pada bagal mata dua, dapat menekan penurunan perkecam- 
bahan sebesar 9\%, namun pada bagal mata satutidak berpengaruh. Tujuan perendaman dengan fungisida sistemik adalah untuk mencegah rusaknya benih karena jamur sekunder dan mencegah penyakit terbawa benih pada tebu. Fungisida benomil merupakan fungisida sistemik. Fungisida ini dapat diserap oleh tanaman dan ditranslokasikan ke seluruh bagian tanaman (Sumardiyono, 2008). Fungisida benomil memiliki spektrum yang luas dan dapat berubah menjadi metilbenzidamizole karbamat apabila diaplikasikan pada permukaan tanaman sehingga akan mengganggu pembelahan inti jamur dan mengganggu sintesa DNA (Widiastuti, 2011). Pada bagal mata satu peran fungisida tidak berpengaruh karena penurunan perkecambahan didominasi oleh perlakuan LHWT $50^{\circ} \mathrm{C}$ selama 2 jam dengan penurunan perkecambahan lebih dari $20 \%$.

Pada perkecambahan di rumah kaca perlakuan pre-treatment LHWT yang diikuti post-treatment menunjukkan perkecambahan yang lebih tinggi dibanding LHWT dengan post-treatment. Perkecambahan pada perlakuan pre-tretment LHWT yang diikuti post-treatment pada bagal mata satu lebih tinggi dari kontrol. Hal tersebut karena pre-treatment pada suhu $50^{\circ} \mathrm{C}$ selama 10 menit dapat memecah dormansi benih, sehingga benih tebu mampu berkecambah. Menurut (Brandes, 1984) bahwa terdapat hubungan antara penggunaan hormon auxin dengan perawatan air panas $50^{\circ} \mathrm{C}$ selama 20 menit dibandingkan dengan tanpa perawatan air panas. Hasil penelitian (Brandes, 1984) menunjukkan bahwa jumlah auxin menurun setelah 1 jam sebesar $10 \%$, penurunan 1 hari mencapai $23 \%$ dan 2 hari menurun $41 \%$. Penurunan jumlah auxin dapat memacu perkecambahan. Auksin bekerja berlawanan dengan sitokinin. Apabila auksin turun makasitokinin bekerja memacu pertumbuhan tunas aksilar sehingga mendorong pertumbuhan tunas (Campbell, 2002).

\section{Pengaruh LHWT Terhadap Perubahan Fisik Mata Tunas}

Hasil analisis statistik menunjukkan bahwa tidak ada interaksi antara varietas dan perlakuan LHWT terhadap perubahan fisik mata tunas. Perubahan fisik mata tunas tidak berkorelasi dengan persentase perkecambahan. Perbedaan persentase perubahan fisik mata tunas menunjukkan bahwa setiap varietas memiliki kondisi fisik lapisan penutup mata tunas yang berbedabeda (Jati, 2015).

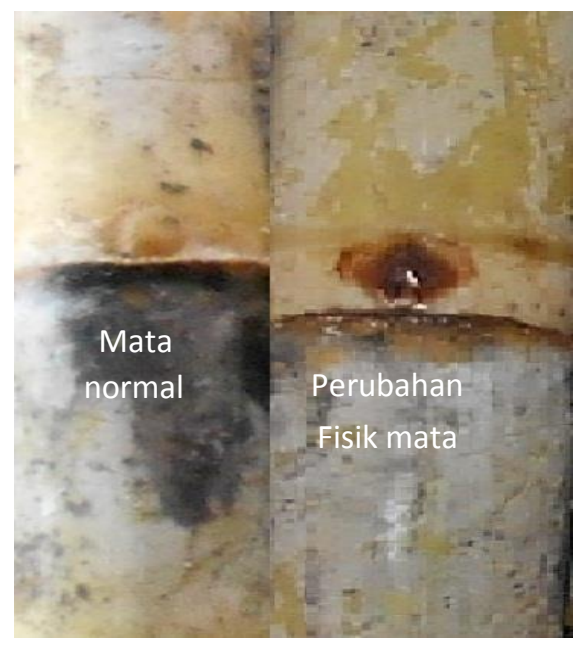

Gambar 2. Perubahan fisik mata tunas tebu.

Figure 2. Physical changes of sugarcane budsett.

Perubahan fisik mata tunas yang terjadi adalah mata tunas berubah warna menjadi kecoklatan dan pada varietas tertentu mengalami kerutan (Gambar 2.) Pengaruh mandiri varietas terhadap perubahan fisik mata tunas ditunjukkan pada Tabel 3. Hasil pengamatan menunjukkan bahwa varietas Bululawang 
merupakan varietas yang lebih tahan terhadap perubahan fisik mata tunas dibandingkan varietas lainnya. Varietas yang mengalami perubahan fisik tertinggi adalah varietas VMC 76-16 yang mencapai $35,27 \%$.

Tabel 3. Pengaruh mandiri varietas tebu terhadap perubahan fisik mata tunas

Table 3. Independent effect of sugarcane varieties on physical changes in budsett

\begin{tabular}{lc}
\hline Varietas & $\begin{array}{c}\text { Perubahan Fisik } \\
\text { Mata Tunas (\%) } \\
\text { Varieties }\end{array}$ \\
$\begin{array}{c}\text { Physical Changes in } \\
\text { Budsett (\%) }\end{array}$ \\
\hline PSDK 923 & $26,94 \mathrm{~b}$ \\
Bululawang & $4,44 \mathrm{~d}$ \\
VMC 76-16 & $35,27 \mathrm{a}$ \\
PSJK 922 & $10,56 \mathrm{c}$ \\
PS 862 & $12,78 \mathrm{c}$ \\
\hline
\end{tabular}

Angka-angka yang diikuti huruf yang sama menunjukkan tidak berbeda nyata berdasarkan uji BNT $5 \%$.

The numbers followed by the same letter showed no significant different based on the $5 \%$ LSD test.

\section{Pengaruh LHWT Terhadap Taksasi Produktivitas Benih}

Hasil uji statistik terhadap parameter produksi menunjukkan tidakterjadi interaksi antara varietas dan perlakuan LHWT. Hasil pengamatan terhadap produksi benih pada varietas bina disajikan pada Tabel 5. Pada Tabel tersebut terlihat bahwa hasil taksasi yang terendah adalah varietas Bululawang dengan nilai $397,28 \mathrm{ku} \mathrm{ha}^{-1}$ karena berat batang tebu paling rendah. Varietas Bululawang setelah dirawat air panas memiliki respon perkecambahan yang cukup lambat dibandingkan varietas lainnya (Jati, 2015). Sesuai dengan pedoman sertifikasi tahun 2009, taksasi produksi benih tebu minimal sebesar 400 $\mathrm{ku} \mathrm{ha}^{-1}$. Dengan demikian taksasi hasil dari varietas ini belum memenuhi syarat pedoman sertifikasi benih tebu.

Tabel 4. Pengaruh mandiri perlakuan LHWT terhadap perubahan fisik mata tunas tebu

Table 4. Independent effect of LHWT treatment on physical changes in sugarcane budsett

\begin{tabular}{cc}
\hline Varietas & $\begin{array}{c}\text { Perubahan Fisik } \\
\text { Mata Tunas (\%) } \\
\text { Physical Changes } \\
\text { in Budsett (\%) }\end{array}$ \\
\hline P1 (K bagal mata 1) & $0,00 \mathrm{c}$ \\
P2 (K bagal mata 2) & $0,00 \mathrm{c}$ \\
P3 (LHWT + Post $(\mathrm{F}+$ & $32,00 \mathrm{a}$ \\
U) ) mata 1 & $30,00 \mathrm{a}$ \\
P4 (LHWT + Post (F + \\
U ) ) mata 2 \\
P5 (Pre + LHWT + Post \\
(F+ U)) mata 1 \\
P6 (Pre + LHWT + Post \\
(F + U) mata 2
\end{tabular}

Angka-angka yang diikuti huruf yang sama menunjukkan tidak berbeda nyata berdasarkan uji BNT $5 \%$.

The numbers followed by the same letter showed no significant different based on the 5\% LSD test.

Perkecambahan varietas yang lambat menjadi salah satu penyebab rendahnya produksi benih. Hal tersebut terlihat dari data jumlah batang tiap juring dan berat/batang varietas Bululawang yang kurang optimal pada saatdilakukan taksasi yaitu pada umur 6 bulan. Selain itu dapat pula disebabkan jumlah anakan varietas 
Bululawang yang lebih rendah pada perlakuan P5 dan P6 (Tabel 6). Hasil dibandingkan varietas VMC 76-16, taksasi sesuai dengan hasil perkecambahan meskipun prosentase perkecambahan umur 1 bulan yang dilakukan di rumah hampir sama. Empat varietas lainnya kaca. Hal tersebut menunjukkan bahwa memiliki produktivitas yang tidak berbeda pengaruh LHWT pada fase perkecambahan nyata antara $552 \mathrm{ku} \mathrm{ha}^{-1}-633 \mathrm{ku} \mathrm{ha}^{-1}$ akan mempengaruhi produktivitas benih dengan taksasi produksi tertinggi pada tebu. LHWT tanpa pre-treatment pada P3 varietas PSJK 922. Pengaruh perlakuan LHWT post-treatment atau perlakuan P3 dan P4 dapat menyebabkan turunnya produktivitas benih tebu, sebaliknya LHWT dengan pre-treatment dapat meningkatkan produktivitas benih tebu di kebun. kontrol yaitu P1 dan P2 maupun perlakuan pre-treatment LHWT dan post-treatment

Tabel 5. Pengaruh mandiri varietas terhadap taksasi produksi benih tebu

Table 5. Independent effect of variety on seed cane production estimates

\begin{tabular}{ccccccc}
\hline $\begin{array}{c}\text { Varietas } \\
\text { Varieties }\end{array}$ & $\begin{array}{c}\text { Mosaik } \\
(\%) \\
\text { Mosaic } \\
(\%)\end{array}$ & $\begin{array}{c}\text { Penggerek } \\
\text { Pucuk }(\%)\end{array}$ & $\begin{array}{c}\text { Penggerek } \\
\text { Batang(\%) } \\
(\%)\end{array}$ & $\begin{array}{c}\text { Jumlah } \\
\text { Batang/ } \\
\text { Juring }\end{array}$ & $\begin{array}{c}\text { Berat batang } \\
(\mathrm{kg})\end{array}$ & $\begin{array}{c}\text { Taksasi } \\
\mathrm{ku} / \mathrm{ha})\end{array}$ \\
$\begin{array}{c}\text { Stem } \text { Borer } \\
(\%)\end{array}$ & $\begin{array}{c}\text { Number of } \\
\text { stem/ Row }\end{array}$ & $\begin{array}{c}\text { Weight } \\
\text { of stem }\end{array}$ & $\begin{array}{c}\text { Producti- } \\
\text { vities }\end{array}$ \\
\hline PSDK 923 & 0,33 & 1,89 & 1,56 & 73,78 & 0,6628 & $583,06 \mathrm{a}$ \\
Bululawang & 0,83 & 1,89 & 1,00 & 59,11 & 0,5278 & $397,28 \mathrm{~b}$ \\
VMC 76-16 & 10,17 & 2,11 & 0,50 & 71,44 & 0,7150 & $577,94 \mathrm{a}$ \\
PSJK 922 & 0,00 & 1,72 & 3,00 & 82,00 & 0,6283 & $633,28 \mathrm{a}$ \\
PS 862 & 0,00 & 2,22 & 1,44 & 55,78 & 0,7233 & $552,44 \mathrm{ab}$ \\
\hline
\end{tabular}

Angka-angka yang diikuti huruf yang sama menunjukkan tidak berbeda nyata berdasarkan uji BNT $5 \%$.

The numbers followed by the same letter showed no significant difference based on the 5\% LSD test 
Tabel 6. Pengaruh mandiri perlakuan LHWT terhadap taksasi produksi benih tebu

Table 6. Independent effect of LHWT treatment on seed cane production estimates

\begin{tabular}{|c|c|c|c|c|c|c|}
\hline $\begin{array}{l}\text { Perlakuan } \\
\text { Treatment }\end{array}$ & $\begin{array}{c}\text { Mosaik } \\
(\%) \\
\text { Mosaic } \\
(\%)\end{array}$ & $\begin{array}{c}\text { Penggerek } \\
\text { pucuk (\%) } \\
\text { Top borer } \\
(\%)\end{array}$ & $\begin{array}{c}\text { Penggerek } \\
\text { batang }(\%) \\
\text { Stem borer } \\
(\%)\end{array}$ & $\begin{array}{c}\text { Jumlah } \\
\text { Batang/ } \\
\text { Juring } \\
\text { Number } \\
\text { of } \\
\text { stem/row }\end{array}$ & $\begin{array}{c}\text { Berat } \\
\text { batang } \\
(\mathrm{kg}) \\
\text { Weight } \\
\text { ofstem }\end{array}$ & $\begin{array}{c}\text { Taksasi } \\
\text { ku/ha) } \\
\text { Prediction } \\
\text { of } \\
\text { Producti- } \\
\text { vities }\end{array}$ \\
\hline P1 (K bagal mata 1$)$ & 2,93 & 2,07 & 1,40 & 72,80 & 0,68 & 594,07 a \\
\hline P2 (K bagal mata 2$)$ & 2,20 & 0,80 & 3,00 & 75,33 & 0,66 & $613,87 \mathrm{a}$ \\
\hline $\begin{array}{l}\mathrm{P} 3(\mathrm{LHWT}+\text { Post }(\mathrm{F}+ \\
\mathrm{U})) \text { mata } 1\end{array}$ & 1,07 & 3,67 & 0,67 & 52,67 & 0,58 & $369,07 \mathrm{~b}$ \\
\hline $\begin{array}{l}\mathrm{P} 4(\mathrm{LHWT}+\text { Post }(\mathrm{F}+ \\
\mathrm{U})) \text { mata } 2\end{array}$ & 0,00 & 2,20 & 0,93 & 56,13 & 0,61 & $442,67 \mathrm{~b}$ \\
\hline $\begin{array}{c}\text { P5 }(\text { Pre + LHWT + Post } \\
(\mathrm{F}+\mathrm{U})) \text { mata } 1\end{array}$ & 3,33 & 1,67 & 0,87 & 78,67 & 0,70 & $669,40 \mathrm{a}$ \\
\hline $\begin{array}{c}\mathrm{P} 6(\text { Pre }+\mathrm{LHWT}+\text { Post } \\
(\mathrm{F}+\mathrm{U})) \text { mata } 2\end{array}$ & 4,07 & 1,40 & 2,13 & 74,93 & 0,63 & $603,73 \mathrm{a}$ \\
\hline
\end{tabular}

Angka-angka yang diikuti huruf yang sama menunjukkan tidak berbeda nyata berdasarkan uji BNT $5 \%$.

The numbers followed by the same letter showed no significant difference based on the 5\% LSD test

\section{KESIMPULAN}

Perawatan benih tebu yang didahului dengan pre-treatment air panas pada suhu $50^{\circ} \mathrm{C}$ selama 10 menit yang diikuti dengan LHWT $\left(50^{\circ} \mathrm{C}\right.$ selama 2 jam $)$ dan post treatment dengan perendaman dalam larutan fungisida dan urea dapat digunakan sebagai salah satu metode untuk mendapatkan benih yang sehat tanpa menyebabkan terjadinya penurunan perkecambahan pada benih tebu. Benih yang diperlakukan LHWT perlu didederkan terlebih dahulu. Perlakuan
LHWT dengan pre-treatment $\left(50^{\circ} \mathrm{C}\right.$ selama 10 menit) dapat meningkatkan produktivitas benih tebu dibandingkan LHWT tanpa pre-treatment.

\section{UCAPAN TERIMAKASIH}

Penulis mengucapkan terimakasih kepada Dr. Cece Soehara dan Dr. Setyono Yudo Tyasmoro, Teddy Bahaduri, STP serta pihak yang telah membantu sehingga penelitian ini dapat terlaksana dengan baik. 


\section{DAFTAR PUSTAKA}

Bailey, R.A. and P.H. Fox. 1984. A large scale diagnostic service for ratoon stunting disease. Proceeding Annual Congres South Africa Sugarcane Technologist Association 15: 213 217.

Brandes, E.W. and J. Van Overbeek. 1948. Auxin relations in hot water treated sugarcane stem. Journal of Agricultural Research Vol. 77: 223238.

Campbell, N.A. \& J. B. Reece.2002. Biology. Sixth Edition, Pearson Education.Inc. San Francisco.1175 p.

Carvalho, G., T.G.E.R. da Silva, A.T. Munhoz, C. B. Monteiro-vitorello, R. A Azevedo, M. Melotto, L.E.A. Camargo. 2016. Development of $\mathrm{q}$ PCR for Leifsonia xyli subp xyli and quantification of the effect of heat treatment on sugarcane cutting on Lxx. Crop Protection. 80 : 51-55.

Croft, B.J., N. Thompson \& R.C. Magarey. 2011. Introduction To sugarcane Quarantine: Instructions for staff of research organisations involved in sugarcane research. BSES Limited.Woodoford. 35 p.

Goodall, J.L., R.A. Bailey \& M.D. Laing. 1998. Improving germination of single-budded sugarcane setts using thermotherapy and fungicide treatments. Proceeding of South Africa Sugarcane Technologist Association. 72:85-90.

Grisham, M. P. 1991. Effect of ratoon stunting disease on yield of sugarcane grown in multiple three-year plantings. Phytopathology. 81: 337-340.

Handojo, H. 1982. Penyakit Pembuluh di Indonesia. Balai Penelitian Perusahaan Perkebunan Gula, Pasuruan. $13 \mathrm{hlm}$.

Hardy, J.G. 1973. Results from seedcane germination experiments, including the use of urea withhot water treatment for control of ratoon stunting disease
(RSD).

http://citeseerx.ist.psu.edu/viewdoc/do wnload?doi=10.1.1.451.1308\&rep=rep 1\&type=pdfmodified 5/4/2017. 6 p.

Haryuni, 2015. Pengaruh perendaman air panas dan dosis Trichoderma sp. terhadap kualitas jaringan pada pertumbuhan benih asal mata tunas tebu (Saccharum officinarum). Jurnal Biosaintifika 7 : 1-7.

Irawan \& A. Kristini. 2000. Seri Pedoman P3GI Perawatan Air Panas Terhadap Bibit Tebu. Pusat Penelitian Perkebunan Gula Indonesia. Pasuruan. $8 \mathrm{hlm}$.

Jati, W.W. 2015. Respon perkecambahan 12 varietas tebu bina terhadap perlakuan benih Hot Water Treatment. Majalah Penelitian Gula 51: 1-9.

King, N.J., R.W. Mungomery \& C.G. Hughes. 1978. Manual of Cane Growing. 2nd Ed. Augus and Robertson, Sydney, Australia. 375 p.

Kurniawan, S., A. Widiastuti, \& Y.M.S. Maryudani.2008. Pengaruh perlakuan uap air panas dengan sistem pemanasan terbuka terhadap kesehatan dan viabilitas benih jaung. Jurnal Perlindungan Tanaman Indonesia. 14: 63-69.

Mutonyi, J. \& H. Nyongesa.2016. Incidence and prevalence of ratoon stunting disease (Leifsonia xyli Subsp. xyli, Evtushenko) in The Mumias sugarcane growing zone Kenya. International Organization of Scientific Research Journal of Agriculture and Veterinary Science. 9 : 28-31.

Permana, A.D., M. Bhaskara, E. Widaryanto, 2015. Pengaruh perbedaan umur bibit single bud planting dengan pemupukan nitrogen pada pertumbuhan awal tanaman tebu (Saccharum officonarum L.). Jurnal Produksi Tanaman 3: 424-432.

Prawirosemadi, M. 2011. DasarDasarTeknologi Budidaya Tebu dan 
Pengolahan Hasilnya. Universitas Negeri Malang. Malang. $811 \mathrm{hlm}$

Putra, L.K. 1997. Perlunya memperhatikan kesehatan bibit tebu dan upaya penyediaannya. Gula Indonesia 22:1316.

Putra, L.K. 2005. Penyehatan bibit dengan perawatan air panas. Materi Training of Trainers. Sekolah Lapang Tani Pembibitan Tebu. P3GI, Pasuruan. 7 hlm.

Sugiyarta,E.1993. Teknologi mikroprapagasi untuk penyediaan bibit tebu varietas unggul yang sehat. Gula Indonesia 18:15-16.

Sumardiyono, C. 2018. Ketahanan jamur terhadap fungisida di Indonesia. Jurnal Perlindungan Tanaman Indonesia 14: $1-5$.

Tiwari, A.K., S.K. Vishwakarna, P. Kumar, N. Pandey \& M. Lal. 2012. Ratoon stunting disease (Leifsonia xyli) of sugarcane. Plant Knowledge Journal 1: 20-24

Viswanathan, R. 2016. Varietal degeneration in sugarcane and its managment in India. Sugar Technology $18: 1-7$.

Widiastuti, A., W. Agustina, A. Wibowo \& C. Sumardiyono. 2011. Uji efektivitas pestisida terhadap beberapa patogen penyakit penting pada buah naga (Hylocereus sp.) secara in vitro. Jurnal Perlindungan Tanaman Indonesia 17: 73-76.

Singh, A. K., Singh, S. N., Rao, A. K. and Sharma, M. L. 2008. Spacing, nitrogen, seed rate and seed size requirement of an earlymaturing sugarcane variety $\mathrm{CoS} 96268$ for higher productivity incalcarious soils. Indian Journal of Agronomy. 23: 28-30

\section{Lampiran}

Rumus perhitungan :

$$
\begin{aligned}
& \text { Berat batang }=\frac{\text { berat batang dalam satu rumpun }}{\text { jumlah batang dalam satu rumpun }} \\
& \text { Jumlah juring/ha }=\frac{\text { satuan ha dalam meter }(10000 \mathrm{~m} 2)}{[\text { PKP }(\mathrm{m}) \times(\text { panjang juring }+ \text { gantangan }+ \text { got })(\mathrm{m})]} \times \text { tara kebun }(0,94) \\
& \% \text { Mosaik }=\frac{\text { jumlah rumpun terserang }}{\text { jumlah rumpun dalam satu juring }} \times 100 \% \\
& \% \text { Penggerek pucuk }=\frac{\text { jumlah batang terserang }}{\text { jumlah batang dalam satu juring }} \times 100 \% \\
& \text { jumlah ruas terserang }
\end{aligned}
$$


Taksasi Produksi $=$ jumlah juring/ha $\mathrm{x}$ jumlah batang sehat per juring ${ }^{*}$ x berat batang

*) Jumlah batang sehat $=$ jumlah batang per juring- $\left(\right.$ batang terserang mosaik $\left.{ }^{* *}\right)+$ batang terserang penggerek pucuk)

**) mosaik dinyatakan dalam satuan rumpun diubah ke satuan batang

Taksasi Penangkaran $=\frac{\left.\text { jumlah batang sehat } / \text { ha } X \text { jumlah ruas sehat } / \text { batang }^{*}\right)}{\left.\text { keperluan benih/ha }{ }^{* *}\right)}$
$*$ Jumlah ruas sehat/batang $=\begin{aligned} & \text { jumlah ruas/batang }- \text { jumlah ruas terserang penggerek } \\ & \text { pucuk }\end{aligned}$

**) Keperluan benih/ha $=$ jumlah juring/ha $\mathrm{x}$ jumlah benih (mata/ruas) per meter $\mathrm{x}$ panjang juring 